\title{
CORRELATIONS OF PHYSICAL ACTIVITY AND PSYCHOSOMATIC COMPLAINTS OF 10-15-YEAR-OLD SCHOOLCHILDREN
}

\author{
Elvyra Grinienè, Gintarė Jankauskaitė \\ Lithuanian Sports University, Kaunas, Lithuania
}

\begin{abstract}
Research background and hypothesis. The society is concerned not only about worsening student health, but also medically unexplainable psychosomatic complaints which can be the risk factor for various health and behavioural problems (WHO, 2006).

Research aim was to determine the dependence of psychosomatic complaints experienced by 10-15-year-old students on their physical activity, age and gender.

Research methods. With reference to the international questionnaire of student health and lifestyle (WHO, 2006), a questionnaire containing 31 questions was constructed for the research. Its answers about physical activity were coded from 1 - never to 5, 7, 8 - different variants of often. The questionnaire survey was conducted in February, 2012, in two schools of Kaunas city. The research participants were 293 V-VIII-grade 10-15-year-old students. The answers were analysed with reference to students' physical activity, age and gender.

Research results. Most respondents were moderately or intensively physically active: more of them were younger (10-12 years) than older (13-15 years), and there were more boys than girls. The students often exercised and did sports individually. Health self-assessment as good or even perfect was demonstrated by most physically active students. During the last 6 months they more rarely felt various psychosomatic complaints, especially related to negative emotions. Students of low physical activity felt more various psychosomatic complaints.

Conclusion. Physically more active students rarely experienced psychosomatic complaints, which show that physical activity is a significant factor reducing negative psychosomatic emotions.
\end{abstract}

Keywords: schoolchildren's physical activity, health self-assessment, psychosomatic complaints.

\section{INTRODUCTION}

$\mathrm{T}$ The society is concerned about the worsening health of the students (WHO, 2006). According to the data of the international (HBSC) programme studies, in Lithuania every third 11, 13 and 15-year-old student evaluates his/her health as satisfactory or poor (Zaborskis, Vareikiené, 2008). Besides, students indicate various psychosomatic complaints, such as various pains (head, back, abdomen, etc.), chronic fatigue, infirmity, increased sensibility to various stimuli, sleep disorders and others (Naujokaite, 2011; Januškevičiene et al., 2011). The symptoms, the origin of which are medically unexplainable, are not distinguished by organ pathology, they lack effective treatment ways and are attributed to psychosomatic area (Kelly et al., 2010; Madge et al., 2011) This can become a risk factor for the emergence of various problems of mental health and behaviour (Hesketh et al., 2010; Schrami et al., 2011 ). Eventually this can arouse real pathological disorders: cardiac, gut activity, skin abnormalities and other organ activity disorders (Eriksson, Sellstrom, 2010; Veek et al., 2010).

Numerous studies have proved that health of children and adolescents depend on the influence of casual physical activity (Janssen, LeBlanc, 2010). 
In all cases, physical activity improves the quality of life, develops more positive self-perception, directly positively influences psychological health. In this case manifestation of physical activity is understood as active rest: doing sports, exercising, doing housework or any other activity related to energy consumption (Jankauskienè, 2008; Guthoid et al., 2010). Duration of physical activity, with reference to child's age, has to constitute $1 / 3-1 / 6$ of time devoted to mental activity (Armonienè, 2007.) The data of various authors in Lithuania show that most students are not sufficiently physically active and the decrease of physical activity of adolescents can be observed (Blauzdys, Bagdoniené, 2007; Strukčinskienė et al., 2011).

Despite the fact that many Lithuanian researchers (Jankauskiene, 2008; Laskienè, 2008) paid much attention to the studies analysing physical activity and its influence on psychical health, there is still a lack of studies defining the correlations of student's physical activity and psychosomatic complaints in the aspect of students' different age and gender.

Hypothesis. Physical activity is one of the factors which will reduce negative emotions, and there will be fewer psyhosomatic complaints.

Research aim was to determine the dependence of the frequency of psychosomatic complaints experienced by V-VIII-grade (10-15-year-old) students on their physical activity.

\section{RESEARCH METHODS}

Participants. The study participants were 293 V-VIII-grade students of two schools of Kaunas city. Among them there were 121 boys and 172 girls, their age was from 10 to15 years. Analysing the frequency of psychosomatic disorders and physical activity of students, we divided them into two groups: younger V-VI grades (10-12 years) and older VII-VIII grades (13-15 years). At the beginning of the questionnaire survey we received the consent of school heads and students' parents. Students were interviewed in February, 2012.

Methods. The main research method employed was a questionnaire survey. The questionnaire was constructed with reference to the international questionnaire of student health and lifestyle (HBSC). There were 31 questions. The answers to the questions about physical activity were coded in 5-, 7-, 8-point scales: from $1-$ never to 5, 7, 8 - different variants of often. Students' physical activity was assessed according to the coded number of points: from 6 to 10 -low physical activity, 11-13 points - moderate physical activity and 14-15 - intensive physical activity. All other questions were assessed according to subjective answer produced: for example, what complains they had or how they assessed their health, etc.

Statistical data analysis was performed using SPSS statistical packet, version 17.0. For the verification of the hypothesis, we used descriptive statistics, Pearson's correlation coefficients and chi squared test. The level of significance was set at $\mathrm{p}<0.05$.

\section{RESEARCH RESULTS}

It can be seen from Table 1 that physical activity depended on students' age and gender. Most participants were intensively or moderately active $(\mathrm{p}<0.00)$. There were more younger $(\mathrm{V}-\mathrm{VI}$ grades) participants who were intensively physically active, and there were significantly more older (VII-VIII grades) moderately physically active students. There were more intensively physically active boys than girls, the number was similar for moderately physically active ones, and there were more girls who were not so physically active $(\mathrm{p}<0.00)$.

Table 1. Schoolchildren's physical activity dependence on their age and gender

\begin{tabular}{|l|c|c|c|}
\hline \multicolumn{4}{|c|}{ Physical activity, \% } \\
\hline \multicolumn{1}{|c|}{ Group } & Intensive & Moderate & Little \\
\hline All subjects & 42.3 & 46.1 & 12.6 \\
\hline V-VI grade & $59.0^{*}$ & 35.0 & 6.0 \\
\hline $\begin{array}{l}\text { VII-VIII } \\
\text { grade }\end{array}$ & 27.0 & $55.0^{*}$ & 18.0 \\
\hline Boys & 50.0 & 46.0 & 4.0 \\
\hline Girls & 35.0 & $75.0 *$ & 21.0 \\
\hline
\end{tabular}

Note. ${ }^{*}-\mathrm{p}<0.01$.

Figure 1 reported on those students who exercised longer during their free time and were engaged in sports so that their breath would become rapid and they sweated, among them there were more younger (V-VI grades) than older (VIIVIII grades) students $(\mathrm{p}<0.00)$, more boys than girls, $(\mathrm{p}<0.001)$. More than one third of the boys exercised and did sports 4 and more hours in a week; one third of the girls (29\%) did not spend any hours for that. 
Figure 1. Students exercising longer during their free time and engaged in some sport so that their breath would become rapid and they sweated frequently

Note. ${ }^{*}-\mathrm{p}=0.0005$.

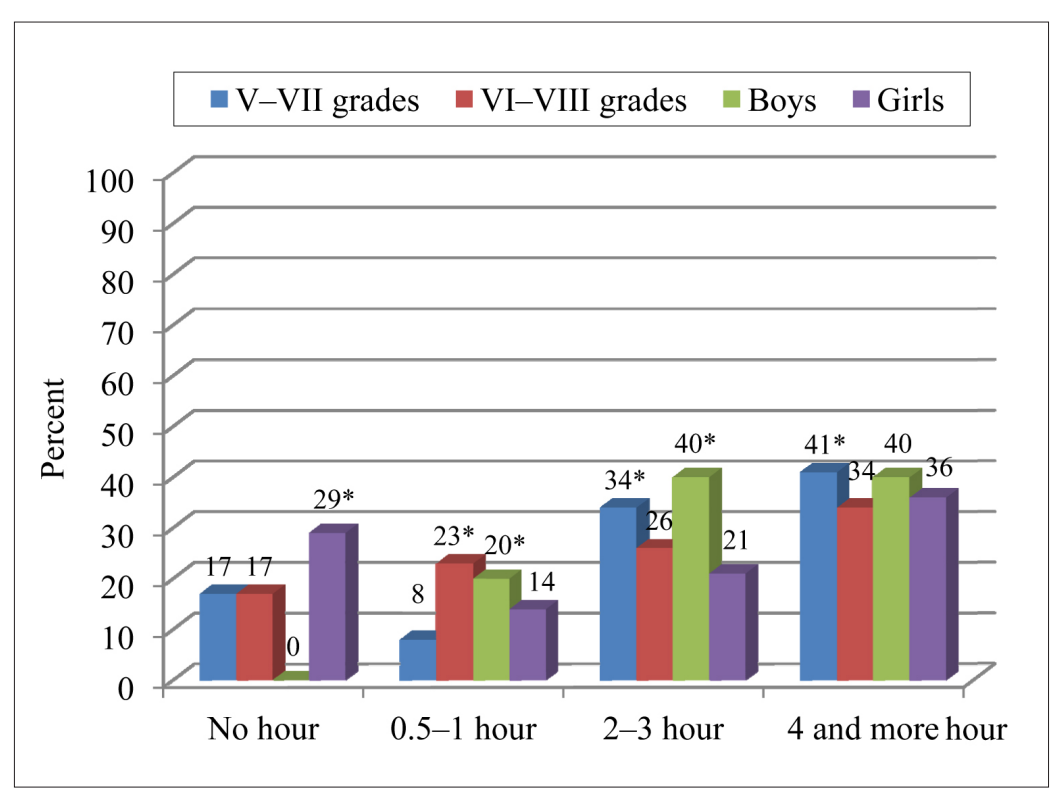

During their free time students usually exercised and did sports individually (33.8\%), in sport clubs (33.1\%), at home (33.4\%) or with friends outdoors $(16.4 \%)$.

Table 2. Dependence of participants' health self-assessment on their physical activity

\begin{tabular}{|l|c|c|c|}
\hline \multicolumn{1}{|c|}{$\begin{array}{c}\text { Health self- } \\
\text { assessment }\end{array}$} & \multicolumn{3}{|c|}{ Physical activity, \% } \\
\hline & Intensive & Moderate & Little \\
\hline Excellent & 40 & $54^{*}$ & 35 \\
\hline Good & $60 *$ & $37^{*}$ & 65 \\
\hline Poor & 0 & $9 *$ & 0 \\
\hline
\end{tabular}

Note. ${ }^{*}-\mathrm{p}<0.01$.

Table 2 shows how the self-assessment of students' health depended on their physical activity. Most students whose physical activity was intensive assessed their health as good $(\mathrm{p}<0.0001)$, those, whose physical activity was moderate, indicated that their health was good or even perfect $(\mathrm{p}<0.001)$, although there were $9 \%$ of students among them who indicated that their health was poor. Younger and older students assessed their health in a similar way. With reference to gender, health assessments differed: more than half of the boys assessed their health as perfect, and only one third of the girls did the same. Besides, $7 \%$ of the participants indicated that their health was poor $(\mathrm{p}<0.001)$.

Despite good self-assessment of health, most participants indicated that they experienced several psychosomatic disorders. Table 3 shows that during the last 6 months, one or several psychosomatic problems were experienced more often than once a week by students of different physical activity, age and both genders. Experiencing various psychosomatic problems was reported by more little physically active students $(28.0 \%)$ than moderately (20.5\%t) and intensively physically active students $(21.6 \%), p<0.00$. Similarly often the complaints were expressed by both younger (36.8\%) and older $(39.2 \% \mathrm{t})$ respondents. The boys $(6.0 \%)$, compared to the girls (24.9\%) had psychosomatic problems significantly more often.

Figure 2 shows that psychosomatic complains which reflect respondents' negative emotions as nervous breakdown, moodiness, irritability, oppression, sadness or worry, were reported more often by students with low physical activity, while intensively physically active respondents rarely or never had negative emotions ( $\mathrm{p}=0.0001)$.

Pearson's correlation analysis demonstrated that the more physically active the students were, the higher was their subjective satisfaction with life (coefficient $0.377, \mathrm{p}=0.0001$ ), they better assessed their health $(0.296, p=0.021)$, they more rarely experienced negative emotions $(-0.304, p=0.004)$. 
Table 3. The frequency of participants' psychosocial complaints more often than week in the period of 6 months

\begin{tabular}{|c|c|c|c|c|c|c|c|}
\hline \multirow{2}{*}{ Disorders } & \multicolumn{3}{|c|}{ Physical activity, \% } & \multicolumn{2}{|c|}{ Grade, \% } & \multicolumn{2}{|c|}{ Gender, \% } \\
\hline & Intensive & Moderate & Low & $\mathbf{V}-\mathbf{V I}$ & VII-VIII & Boys & Girls \\
\hline Headache & 0 & 10 & $35 *$ & 10 & 8 & 0 & $15^{*}$ \\
\hline Bellyache & 20 & 7 & 13 & $27 *$ & 16 & 10 & $22 *$ \\
\hline Stomachache & 30 & 28 & $32 *$ & 26 & 31 & 10 & $29 *$ \\
\hline Backache & 10 & 9 & 32 & $18 *$ & $8^{*}$ & 19 & $36^{*}$ \\
\hline Moodiness & 30 & 28 & 32 & $33 *$ & 26 & 19 & $36^{*}$ \\
\hline Nervous strain & 10 & 27 & $43 *$ & 23 & $49 *$ & 0 & $14^{*}$ \\
\hline Sadness & 40 & 28 & 35 & $43 *$ & 26 & 19 & $36^{*}$ \\
\hline Oppression & 30 & 28 & 32 & 30 & 36 & 29 & $36^{*}$ \\
\hline Irritability & 30 & 28 & 32 & 30 & 36 & 19 & $31 *$ \\
\hline Worry & $40 *$ & 28 & $35^{*}$ & 23 & $35 *$ & 12 & $43 *$ \\
\hline Difficulty falling asleep & 10 & 15 & 10 & 18 & 16 & 10 & $29 *$ \\
\hline Dizziness, weakness & 10 & 10 & 13 & 5 & $12 *$ & 0 & $15 *$ \\
\hline
\end{tabular}

Note. $*-p<0.05$.

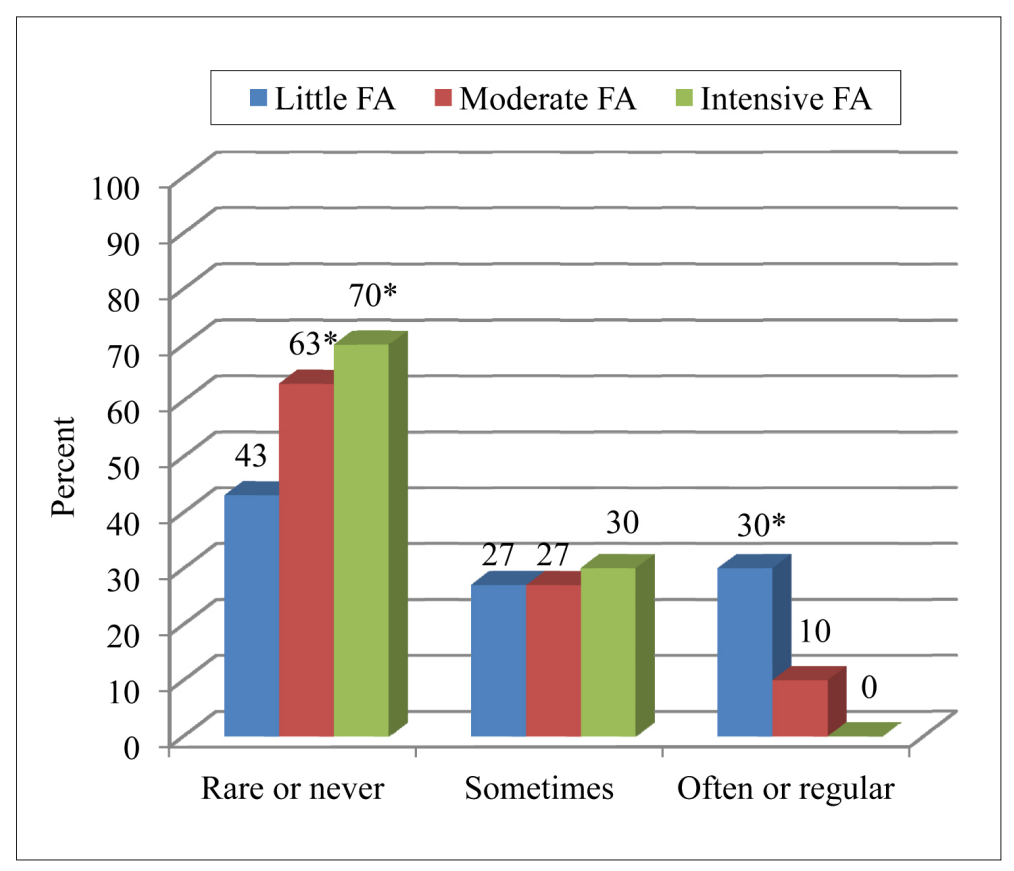

Figure 2. Negative emotions felt in groups of different physical activity levels

Note. $p=0.0001$ 


\section{DISCUSSION}

According to WHO recommendations, the minimum of young person's physical activity has to be 4 hours a week (Zaborskis et al., 1996). As studies of various authors show, most students are not sufficiently physically active (WHO, 2006; Guthoid et al. 2010; Janssen, LeBlanc, 2010). According to the data of B. Strukčinskiene et al. (2011), every third 11-15 year-old boy and every second girl are insufficiently physically active. The data of our accomplished study is similar. In the researched Kaunas city schools, the percentage of students who were insufficiently physically active was 12.6 , moderately physically active $-46.1 \%$, and intensively physically active -12.3 . Data distribution obtained was similar to that received by the authors mentioned above. Among younger students, there were more intensively physically active ones, and among older students there were more moderately and insufficiently physically active ones. This is related to the statement of V. Blauzdys and L. Bagdonienè (2007) that children's physical activity is higher before the sixth grade, in the older age it begins decreasing. Besides, among our researched boys, there were more intensively physically active research participants. While assessing the frequency of duration of student exercising and doing sports a week so as to make the breath more rapid and to sweat, we also observed a consistent pattern that younger students and boys allocated more time for that.

Referring to the analysis of WHO (HBSC), I. Raudoniūte (2011) ascertained that in Lithuania most students assessed their health unfavourably. Health assessment of our respondents was related to their physical activity: both younger and older physically active students often indicated that their health was good or even perfect. More boys than girls indicated that as well. Similar data claiming that V-VIII grade boys statistically significantly assessed their health better than girls were reported by other authors as well (McCormick et al., 2008).

Recently, more often the attention has been paid to students' self-feeling both at school and during their leisure time, the spread of psychosomatic complaints, their causes, possibilities to decrease their spread and improve students' self-feeling (Hesketh et al., 2010; Veek et al., 2010; Schrami et al., 2011). Our respondent students indicated that they at least once a week experienced one or another psychosomatic problem. Among them, there were more of those who suffered from several disorders. The frequency of psychosomatic complaints of different character differed: less physically active students often complained about head and back pains, nervous strain and worries compared to intensively and moderately physically active students $(\mathrm{p}<0.05)$. The majority of younger students complained about stomach ache, back pains, bad mood and sadness, and more of older students complained of nervous strain and anxiety. All those complaints were more characteristic of girls than boys $(p<0.05)$. Girls more often had headaches or dizziness, they were worried, felt nervous strain, and they had stomach-ache and back pains and found it difficult to go to sleep. Therefore, our study revealed that among secondary school students, psychosomatic complaints could be found quite often and that depended on students' physical activity. More physically active students better assessed their health, more rarely experienced psychosomatic complaints related to negative emotions. Those findings proved our hypothesis that more physically active students more rarely had psychosomatic complaints and physical activity was one of the factors of improving students' self-feeling.

\section{CONCLUSIONS AND PERSPECTIVES}

1. Physical activity of most students participating in our research was moderate or intensive, among them there were more younger than older students, more boys than girls.

2. More physically active students, younger than older, boys than girls more often indicated that their health was good or perfect.

3. More students who more often than once a week experienced psychosomatic problems were among less physically active ones, in senior classes and among the girls.

4. More physically active students more rarely experienced psychosomatic problems and that shows that physical activity is one of the factors reducing negative emotions.

Human Subject Approval Statement. Permission to recruit the research participants was given by the heads of the schools, all respondents of the school and by the schoolchildren's parents. All respondents gave informed consent to participate in the study. We also state that research reported above was undertaken in compliance with the Declaration of Helsinki.

The authors state no conflict of interest. 


\section{REFERENCES}

Armonienè J. (2007). Mokinių fizinis aktyvumas ir sveikata. Pedagogika, 85, 116-121.

Blauzdys V., Bagdonienė L. (2007). Mokiniu teigiamo požiūrio ì kūno kultūrq kaip mokymosi dalykq ugdymas, didinant jo prasminguma: monografija. Vilnius: VPU 1-kla.

Eriksson, U., Sellstrom, E. (2010). School demands and subjective health complaints among Swedish schoolchildren: A multilevel study. Scandinavian Journal of Public Health, 38 (4), 344-350.

Guthoid, R., Cowan, M. J., Autenrieth, C. S., Kann, L, Riley, L. M. (2010). Physical activity and sedentary behavior among schoolchildren: 34-country comparison. Journal of Pediatrics, 157 (1), 43-49.

Hesketh, T., Zhen, Y., Lu, L., Dong Jun, Y. X., Xing, Z. W. (2010). Stress and psychosomatic symptoms in Chinese school children: A cross-sectional survey. Archives of Disease in Childhood, 10 (95), 136-140.

Jankauskienè, R. (2008) Lietuvos gyventojų fizinio aktyvumo skatinimo strategija: kūno kultūra ar kūno kultas? Medicina (Kaunas), 44 (5), 346-355.

Janssen, I., LeBlanc, A. G. (2010). Systematic review of the health benefits of physical activity and fitness in school-aged children and youth. International Journal of Behavioral Nutrition and Physical Activity, 7 (40), $1-16$.

Januškevičienè, A., Vaitkaitienè, E., Albavičiūte, E. et al. (2011). Mokyklinio amžiaus vaikų galvos skausmų paplitimas ir sąsajos su šeimos socialine ir ekonomine padètimi (HBSC tyrimas). Lietuvos bendrosios praktikos gydytojas, 15 (5), 336-342.

Kelly, C., Molcho, M., Doyle, P., Gabhainn, N. S. (2010). Psychosomatic symptoms among schoolchildren. International Journal of Adolescent Medicine and Health, 22 (2), 229-235.

Laskienè, S. (2008). Jaunesnio mokyklinio amžiaus vaiku subjektyvaus išvaizdos ir sveikatos vertinimo bei fizinio aktyvumo sąsajos. Visuomenès sveikata, 3 (42), 31-35.

Madge, N., Hawton, K., McMahon, E. M. et al. (2011). Psychological characteristics of stressful life events and deliberate self-defence: Findings from the Child and Adolescent self-harm in Europe (CHSE) study. European Child and Adolescent Psychiatry, 20, 499-508.

McCormick, B. P., Frey, G., Chun, S., Sibthop, J., Gaji, C. T. (2008). Predicting transitory mood from physical activity level among people with severe mental illness in two cultures. International Journal of Social Psychiatry, 54 (6), 527-538.

Naujokaite, I. (2011). Mediciniškai nepaaiškinami simptomai sveikatos priežiūros sistemoje Kultūra ir visuomene: socialiniu tyrimu žurnalas, 1 (2), 131-146.

Raudoniūtè, I. (2011). Tyrimo „Mokyklinio amžiaus vaiku sveikata ir gyvensena " (HBSC): duomenu analizé. Kaunas: Kauno miesto savivaldybès Visuomenès sveikatos biuras.

Schrami, K., Perski, A., Gross, I. G., Simonsson-Samecki, M. (2011). Stress symptoms among adolescents: The role of subjective psychosiocial condition, lifestyle and selfesteem. Journal of Adolescence, 31 (5), 987-996.

Strukčinskienė, B., Kurlys, D., Griškonis, S., Raistenskis, J. (2011). Mokyklinio amžiaus vaikų sveikos gyvensenos ypatumai fizinio aktyvumo aspektu. Sveikatos mokslai: visuomenès sveikata, medicina, slauga, 21 (7), 46-50.

Veek, S. M., Derkx, H. H., Haan, E., Benninga, M. A., Boer, F. (2010). Abdominal pain in Dutch schoolchildren: Relation with physical and psychological comorbid complaints in children and their parents. Journal of Pediatric Gastroenterology and Nutrition, 51 (4), 481-487.

WHO. (2006). Health Behavior in school-aged Children: (HBSC) Series. Inequalities in Young Peoples' Health: 2005/2006 International Report.

Zaborskis, A., Vareikienė, I. (2008). Patyčios mokykloje ir jų sąsajos su moksleiviu sveikata bei gyvensena. Medicina (Kaunas), 44 (3), 232-239.

Zaborskis, A., Žemaitienè, N., Šumskas, L., Diržytė, A. (1996). Moksleivių gyvenimo būdas ir sveikata 1994. Vilnius: Lietuvos Respublikos Švietimo ir mokslo ministerijos leidybos centras. 